\title{
SPECIAL INTEREST GROUP FOCUSES ON TRAINING NEEDS
}

$\sqrt{1}$ he establishment of 14 Public Health Units and the continuing evolution of the new public health infrastructure in NSW has meant that many of those now working in the public health network perceive they have inadequate formal training to meet their changing roles. Ensuring that all such staff, whatever their professional background, have a minimum level of public health "core skills" has therefore been identified as a priority for 1991-92.

A NSW public health network training special interest group (SIG) with representation from Central Office, metropolitan and rural Units, public health officers, public health nurses, environmental health officers, and specialist staff, was convened in February 1991 to address the training needs of those working in public health.

An audit of the training needs of existing staff was performed in May 1991, with results as indicated in Table 1.

Further training in keyboard skills, core skills in basic epidemiology and biostatistics and competency in computer use for public health were chosen as priorities for training. Following discussion at the July 1991 Unit Directors' meeting, it was resolved to supplement each Public Health Unit budget with enhancement funding conditional on minimum training requirements for staff being met.

Expressions of interest were called from NSW universities to run short courses to address these identified training needs. Replies were received from seven universities indicating their ability to offer further training in these fields. Several courses were felt to have special relevance to public health training needs, as well as being "best buys" in terms of value for money. The first of these courses was run by the Department of Public Health at the University of Sydney. Staff from 12 of the 14 Public Health Units, as well as two Central Office staff, attended. Professional background is shown in Table 2 .

An evaluation completed by 40 of the 41 participants rated the course content "good" (20 per cent) "or very good" (75 per cent), while 33 per cent felt it was "relevant" and 53 per cent felt it was "very relevant" to their working needs.

A further course in biostatistics is planned at the University of Sydney next month, and similar courses will also be held at the University of Newcastle. A distance learning component is also being developed.

For the NSW public health network to come together as a cohesive whole, it is essential that all staff acquire a sound grounding in basic skills. As the network continues to develop, it is hoped that similar opportunities to acquire new skills will be made available to Health Promotions, Aboriginal Health, Women's Health and other health professionals whose work contains a component of public health.

Following the successful establishment of the training program, the Special Interest Group has changed the format of its terms of reference as follows, and will continue to coordinate training:

\section{TERMS OF REFERENCE 1992}

To meet at least twice annually, and to be broadly representative of all grades and categories of professional staff working in the NSW public health network.

To advise on the continuing professional education needs of such staff.

\begin{tabular}{|c|c|c|c|}
\hline \multirow{2}{*}{$\begin{array}{c}\text { Category } \\
\text { of } \\
\text { staff }\end{array}$} & \multicolumn{3}{|c|}{ Training requirements } \\
\hline & 1 & 2 & 3 \\
\hline $\begin{array}{l}\text { Medical } \\
\text { (Directors } \\
\text { \& others) }\end{array}$ & $\begin{array}{l}\text { Biostatistics } \\
\text { (including } \\
\text { statistics } \\
\text { packages) }\end{array}$ & Management & $\begin{array}{l}\text { Epidemiology } \\
\text { and public } \\
\text { health update }\end{array}$ \\
\hline $\begin{array}{l}\text { Public Health } \\
\text { Officers }\end{array}$ & $\begin{array}{l}\text { Epidemiology } \\
\text { and public } \\
\text { health }\end{array}$ & Biostatistics & $\begin{array}{l}\text { Computer } \\
\text { skills }\end{array}$ \\
\hline $\begin{array}{l}\text { Environmental } \\
\text { Health Officers }\end{array}$ & $\begin{array}{l}\text { Computer } \\
\text { skills }\end{array}$ & $\begin{array}{l}\text { Professional } \\
\text { update } \\
\text { (subject areas) }\end{array}$ & Epidemiology \\
\hline $\begin{array}{l}\text { Public Health } \\
\text { Nurses }\end{array}$ & Epidemiology & $\begin{array}{l}\text { Computer } \\
\text { skills }\end{array}$ & Biostatistics \\
\hline $\begin{array}{l}\text { Research/ } \\
\text { Project } \\
\text { Officers }\end{array}$ & Epidemiology & $\begin{array}{l}\text { Computer } \\
\text { skills }\end{array}$ & Biostatistics \\
\hline $\begin{array}{l}\text { Admini- } \\
\text { strative/ } \\
\text { Clerical }\end{array}$ & $\begin{array}{l}\text { Computer } \\
\text { skills }\end{array}$ & $\begin{array}{l}\text { Management } \\
\text { skills }\end{array}$ & $\begin{array}{l}\text { Public relation } \\
\text { skills }\end{array}$ \\
\hline
\end{tabular}

\section{TABLE 2}

\begin{tabular}{|lc|}
\hline \multicolumn{1}{|c|}{ Category } & Number \\
\hline Medical Officer & 3 \\
Environmental Health Officer & 14 \\
Public Health Nurse & 6 \\
Food Inspector & 3 \\
Special Project/Research Officer & 6 \\
Other & 9 \\
\hline Total & 41 \\
\hline
\end{tabular}

- To develop a graded/structured program of skills acquisition for those working in the public health network.

- To encourage "multi-skilling" for staff working within the public health network.

- To act as a "clearing house" for short courses and training opportunities.

- To identify areas where documentation for training purposes would be useful, and to encourage the development of this on an appropriate contract basis.

- To ensure recognition of training and accreditation in a form suitable for future professional advancement.

Our thanks are due to the members of the Training SIG, and the many staff both inside and outside the public health network who have contributed to the successful implementation of training requirements.

David Jeffs, Chairman

Shing Chung Fung, Secretary

on behalf of the NSW public health network training SIG 